\title{
Transatlantica
}

Revue d'études américaines. American Studies Journal

\section{Dean J. Franco, The Border and the Line: Race and Literature in Los Angeles}

\section{Michael Docherty}

\section{(2) OpenEdition}

\section{Journals}

Electronic version

URL: https://journals.openedition.org/transatlantica/11740

DOI: $10.4000 /$ transatlantica. 11740

ISSN: 1765-2766

\section{Publisher}

Association française d'Etudes Américaines (AFEA)

\section{Electronic reference}

Michael Docherty, "Dean J. Franco, The Border and the Line: Race and Literature in Los Angeles",

Transatlantica [Online], 1 | 2018, Online since 01 September 2019, connection on 01 February 2023.

URL: http://journals.openedition.org/transatlantica/11740 ; DOI: https://doi.org/10.4000/

transatlantica. 11740

This text was automatically generated on 1 February 2023.

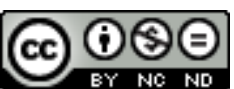

Creative Commons - Attribution-NonCommercial-NoDerivatives 4.0 International - CC BY-NC-ND 4.0 https://creativecommons.org/licenses/by-nc-nd/4.0/ 


\title{
Dean J. Franco, The Border and the Line: Race and Literature in Los Angeles
}

\author{
Michael Docherty
}

\section{REFERENCES}

Dean J. Franco, The Border and the Line: Race and Literature in Los Angeles, Stanford, Stanford University Press, 2019, 224 pages, $\$ 25.95$, ISBN 9781503607774

1 As Dean Franco reminds us in The Border and the Line: Race and Literature in Los Angeles, newspaper magnate Harry Chandler once infamously branded Los Angeles America's "white spot" and sought to keep it that way (132). Throughout his latest book, Franco demonstrates the extent to which the city's multi-ethnic spatialities and textualities have long constituted networks of resistance to and rejection of such monocultural visions as Chandler's. In doing so Franco makes a significant and novel contribution to the study of the United States' most singularly non-singular city, with a work of refreshing disciplinary hybridity-part literary critique, part history, part urban geography, part sociological study, but all Los Angeles.

2 Scholarly ambitions towards totalizing or typifying theories of Los Angeles' cultures tend to founder upon the city's sheer scale and multiplicity-one need only note the increasing circumspection with which the sweeping claims of Reyner Banham are now viewed (Avila 248). When even the grandest schema seem likely to prove inadequate, a more partial and selective approach, one that does not claim completeness in either its corpus or its conclusions, may in that very refusal be the approach that best "gives us a look into what lies beneath" (12). Certainly, Franco's illuminating, incisive, frequently anti-canonical "alternative to exemplariness" is a vindication of this latter model (12).

Franco's introduction begins, with the aid of some personal reflections, by using the "odd fluidity" (2) of the Westside-spanning Pico Boulevard as a case study in the ways that L.A.'s "economic, linguistic, ethnic, sonic, and culinary diversity" map to its geography in forms that are segmented but "run into each other inelegantly" $(1,3)$. He 
then offers an admirably effective capsule account of L.A.'s intersecting histories of race and space-a story of "simultaneous containment and flow" (11). From this, Franco draws the persuasive conclusion that whilst L.A.'s "strategies for producing and managing race are not exceptional", in seeming "so ahistorical" and yet "so segregated" the city has a "quicksilver character" that does render its racial-spatial politics unlike those of any other American city (11).

Chapter 1 focuses primarily on Latinx communities, spaces, and texts. Franco offers a subtle and extensive reading of Helena Maria Víramontes' Boyle Heights-set novel And Their Dogs Came with Them as a text in which "miracles occur as ruptures-both eruptions and interruptions, events that break from the spatial and material configurations of given life and linear time" (51). Franco segues from this to an exploration of the work done in the very neighborhoods represented in Víramontes' novel by Union de Vecinos, a community group which, operating on principles of Marxist-informed liberation theology, "exists to empower residents of Boyle Heights to make active claims of communal ownership upon their neighborhood" (62).

When Boyle Heights was racked by gang violence in the 1980s, as Franco has it, "the neighborhood did not know itself as a neighborhood because "all territory was contested by gangs and police"-residents themselves were unable to occupy it (63). Franco identifies the means by which UV (Union de Vecinos), through positive engagement with gang members and nonviolent but determined occupation of local spaces, all grounded in "the church-based ethos of loving the neighbor", gradually "remapped the neighborhood in the image of the neighbor" (65). Franco argues that UV's work not only demonstrates "the process by which metaphor meets miracle" that Víramontes describes (65); it moreover locates the origins of such a miracle "not in the divine other but in the receptivity to radical possibility among the neighbors themselves"-that is, in a revolutionary hospitality (66).

6 Franco's second chapter again combines a reading of a neighborhood social program with a reading of a literary text. The primary focus is on Budd Schulberg's work as the founder of the Watts Writers Workshop in the immediate aftermath of the 1965 Watts Rebellion. Here, Franco makes extensive use of archival material to trace how Schulberg's "earnest faith in representation in representation was inevitably challenged by [...] more complicated dynamics of law and property" (75). Thus, what began as an "exercise in expression" became equally a "space-making venture" (82), writes Franco. Recognizing the "materiality of the Workshop writers' lives" as both a barrier to expression and the very thing that made such expression so necessary, Schulberg pivoted "from writing to real estate, as he prioritized the establishment of a safe, stable home for writers and artists" (86). In this respect, Franco suggests, the Writers Workshop can be understood as an exercise in neighborliness both psychological and spatial, as Schulberg's "secure perspectives of a West L.A. writer" gave way to "the specific material needs of Watt residents" (83), and Schulberg's efforts to establish Frederick Douglass House as a reading and performance space grounded him more firmly and physically to the community than critiques that he was an "elite, white outsider" (as advanced by local black nationalists) acknowledged (87).

7 Franco is not, however, by any means blind to the ideological and practical limitations in Schulberg's project, and to that end offers a nuanced account elaborating upon James Baldwin's critique thereof, concluding that Baldwin's intervention might bring us closer to the "politics of liberation" that the Workshop briefly gestured towards but 
could not attain. Franco follows his disquisition on Schulberg with an analysis of Paul Beatty's Compton-set 2015 novel The Sellout. In Beatty's novel, writes Franco, politics "simultaneously incorporates and excludes, and perpetuates, the differential logic of insiders and outsiders, winners and losers" (108). In this regard he draws persuasive parallels with both Baldwin's and Schulberg's work-although one wonders if this could have been achieved more effectively had the reading of Beatty been enmeshed more cohesively within the analyses of Baldwin and Schulberg rather than appearing as a largely discrete postscript.

Chapter 3 takes Franco to the Los Angeles Eruv. Eruvin are areas of public space redesignated as domestic by rabbinical authority, thereby enabling Jewish communities to engage in activities on the sabbath that would ordinarily be prohibited outside the home, and L.A.'s is the largest in the West. Franco's reading of the spatial, social, religious, and racial politics of eruv as a mechanism of community or neighborhood formation is typically sophisticated and multidimensional. He alights on the central tension inherent in the emplacement of the eruv's "counter-cartography" within existing (secular) municipal structures-on one hand "the requirement that a non-Jew participate in the formation of the eruv" (125), on the other the "eruv's reliance on public utilities and it necessary 'mixture' with an official non-Jew" (126). Franco suggests compellingly that if the eruv represents "Jewishness as property", its model for doing so manifests an alternative to critical conceptions of "whiteness as property", because its "claim on area" does not "secure possession" (132).

9 As the chapter proceeds, Franco collocates his discussion of the eruv's dialectics of neighborliness with a reading of My Neighborhood, a 2013 documentary about a collaborative effort between leftist Jewish Israelis and a Palestinian family to save the latter's home from Jewish settlers. I am skeptical of Franco's claim that "any discussion of Jewish 'territoriality without sovereignty"' (i.e. his discussion of the eruv's politics) "must take on the broader relationship of diaspora Jews and the State of Israel" (133, italics in both cases mine). This precludes, problematically, the potential for diaspora Jews to occupy space without having the terms of that occupation interrogated through the lens of Israeli politics. It therein by implication seems to impute to diaspora Jews, in any claim they might make upon space, a kind of inevitable metonymic answerability for the actions of a state on the grounds of their ethnic/religious connection with it. Mercifully, however, this troublingly absolute claim is an exception in what is otherwise a nuanced and subtle exploration of Jewishness, neighborliness, community, and cohabitation. Indeed, in using the politics of the eruv to illuminate My Neighbhorhood and vice versa, Franco provides exemplary evidence of how scholars whose work is intimately embedded in a highly particular sense of place can nonetheless respond productively and positively to the transnational turn in critical studies without abandoning their essential localism.

10 In his concluding chapter, Franco returns to Pico Boulevard, and to the sense of the personal that suffused his introduction, with equally compelling results. He recounts how his sense of space, race, and Los Angeles is informed by his own identity as the son of "a Jewish Latina woman growing up in a deracinated, non-ethnic, atheistic home [in which] none of these identity association meant anything for her beyond a troublesome mix of shame and fear and a dose of financial anxiety that she carried forward into our home" (157). Such personal reflections are combined with perceptive remarks on the discliplines of comparative ethnic and literary studies, constituting in effect a 
manifesto for the methodology that has informed the preceding chapters. Franco is especially strong in interrogating the longstanding academic borderline between Jewish studies and ethnic studies-specifically the issue of why "Jews [are] absent-or worse-from the preponderance of ethnic studies projects" (160). It might perhaps be more customary to find such methodological/field-interrogating observations in the introduction, but appearing as a coda they benefit from the contextualization provided by Franco's preceding primary discussions.

11 Franco's theoretical methodology is compellingly syncretic. He draws upon and synthesizes the work of a multiplicity of thinkers, often but not exclusively from broadly Marxist and post-Marxist traditions, to create a methodology entirely appropriate for the city to which it is applied-possessed of a multifariousness and heterogeneity in its constitution that, paradoxically, conspires to create an overarching conceptual cohesion and integrity. Key sources are the works of Emmanuel Levinas, Henri Lefebvre, Alain Badiou, Gilles Deleuze, Ernesto Laclau, Michael Hames-Garcia, and Ed Soja.

Franco's critical omissions, moreover, are as instructive as his inclusions. Mike Davis, for example, receives only one fleeting reference in the main text and another in the notes. Davis has over the past three decades come to cast a long shadow over scholars who seek to use culture to parse the geographies and politics of Los Angeles, and the field will long remain justly indebted to his totemic interventions. It can only speak positively of the current richness and vitality of cultural scholarship on Los Angeles, however, that thinkers of Franco's skill and vision are escaping Davis' frameworks (which, as Casey Shoop has noted, can ultimately "fall prey" to the very same city myths they seek to "debunk and historicize") to chart new courses for the understanding of Los Angeles (Shoop 236). A critical lacuna that seems perhaps more questionable is the relatively limited presence of Jacques Derrida in Franco's book. Levinas' ethics of hospitality and neighborliness are intrinsic to Franco's theorizations of separation and connection between and within communities, but Franco does not explicitly invoke Derrida's vital expansions upon and responses to Levinas' work in this area, despite alluding elsewhere to the former's deconstructions of subjectivity.

13 Franco's structure also effectively models the city he finds: segregation and difference are acknowledged, even embedded, in the form, but this is not to the exclusion or denial of fluidity, of connection, of contiguity or comparability between segmented groupings. The book "doubles back on itself and revisits its own terms because its subjects-race, space, and Los Angeles-do the same" (25). As his title implies, the principal connective fibre that runs throughout Franco's text is the notion that borders and lines are not (or not always) the same thing. Lines on maps may mark certain borders in legality, but borders in a social sense are better understood as spacescontingent, covalent, often unstable or mobile.

As Franco himself acknowledges, this is a conception with debts to Gloria Anzaldúa's "critical coinage of 'the borderlands' as a space of possibility", and to Sandro Mezzadra and Brett Neilson's idea of the "borderscape" (22). (Arguably, it also recalls Frederick Jackson Turner's understanding of frontiers as liminal zones of movement rather than merely dividing lines between types of space-an ironic concordance given Turner's infamous identification of American spatial occupation with white monoculture.) Franco's most significant original contribution, however, lies in mapping the ways in which cultures of Los Angeles are so often defined by the essential tensions that occur 
between the competing meanings of border and line. Intimately concerned with how people cohabit in communities, Franco's field-expanding book ultimately reveals itself to be at root preoccupied with what happens when the border and the line themselves must cohabit in a single space.

\section{BIBLIOGRAPHY}

AVILA, Eric. Popular Culture in the Age of White Flight: Fear and Fantasy in Suburban Los Angeles. Berkeley, University of California Press, 2004.

DAVIS, Mike. City of Quartz: Excavating the Future in Los Angeles. New York, Verso, 2006 [1990].

SHOOP, Casey. "Corpse and Accomplice: Fredric Jameson, Raymond Chandler, and the Representation of History in California". Cultural Critique, vol. 77, Winter 2011, pp. 205-238. DOI: 10.5749/culturalcritique.77.2011.0205

ANZALDÚA, Gloria. Borderlands/La Frontera. San Francisco, Aunt Lute Books, 1987.

MEZZADRA, Sandro and Brett NEILSON. Border as Method: Or, the Multiplication of Labor. Durham, Duke University Press, 2013.

TURNER, Frederick Jackson. The Frontier in American History. New York, Henry Holt, 1921.

INDEX

Subjects: Recensions

\section{AUTHOR}

\section{MICHAEL DOCHERTY}

University of Kent 